\title{
Pengembangan Modul Ajar Storyboard Berbasis Project Based Learning Untuk Siswa Kelas XI Multimedia Di SMK TI Bali Global Singaraja
}

\author{
Komang Dewi Lestari ${ }^{1}$, Ketut Agustini ${ }^{2}$, Nyoman Sugihartini ${ }^{3}$ \\ Program Studi Pendidikan Teknik Informatika \\ Jurusan Teknik Informatika \\ Fakultas Teknik dan Kejuruan \\ Universitas Pendidikan Ganesha \\ Singaraja, Bali \\ E-mail: komangdewilestari1177@gmail.com ${ }^{1}$, ketutagustini@undiksha.ac.id ${ }^{2}$, sugihartini@undiksha.ac.id ${ }^{3}$
}

\begin{abstract}
Abstrak-- Penelitian ini bertujuan untuk mengimplementasikan modul Storyboard berbasis project based learning untuk siswa kelas XI multimedia di SMK TI Bali Global Singaraja. (2) mengetahui respon siswa terhadap pengembangan modul Storyboard berbasis project based learning untuk siswa kelas XI multimedia di SMK TI Bali Global Singaraja. Jenis penelitian yang digunakan dalam penelitian ini adalah Penelitian dan Pengembangan (Research and Development atau $R \& D$ ) dengan model pengembangan Instruksional. Adapun tahapan pada model pengembangan Instruksional diantaranya : tahap mengidentifikasi (Mengidentifikasi kebutuhan instruksional dan menulis tujuan instruksional umum, Melakukan analisis instruksional, Mengidentifikas perilaku dan karakteristik siswa), tahap mengembangkan (Menulis tujuan instruksional khusus, Menulis tes acuan patokan, Menyusun strategi instruksional, Mengembangkan bahan instruksional), dan tahap mengevaluasi dan merevisi (Mendesain dan melaksanakan evaluasi formatif yang termasuk di dalamnya kegiatan merevisi). Penelitian ini melibatkan siswa kelas XI Multimedia SMK TI Bali Global Singaraja. Data tentang sumber belajar siswa diperoleh dengan menggunakan metode wawancara. Validasi modul ajar Storyboard untuk multimedia diperoleh dengan menggunakan angket penilaian.

Adapun analisis data yang dihasilkan untuk uji ahli isi mendapatkan hasil presentase $81,6 \%$, ahli desain mendapatkan hasil presentase $80 \%$, ahli media mendapatkan hasil presentase $95 \%$ sehingga modul berada pada kualifikasi baik dari keseluruhan uji ahli.
\end{abstract}

Kata Kunci: Instruksional, modul ajar, Storyboard

Abstract- This study aims to (1) implement the Storyboard module based on project based learning for multimedia class XI students at SMK TI Bali Global.The type of research used in this study is Research and Development (Research and Development or $R \& D$ ) with the Instructional development model The stages in the Instructional development model include stage of identification (identifying instructional needs and writing general instructional goals, conducting instructional analysis, identifying behavior and characteristics of students), developing stages (writing specific instructional objectives, writing benchmark reference tests, compiling instructional strategies, developing instructional materials), and evaluating and revising stages (Design and implement formative evaluations including revision activities) This study involved students of XI Multimedia class at SMK TI Bali Global Singaraja. Data about student learning resources are obtained using the interview method. Validation of the Storyboard teaching module for multimedia was obtained using an assessment questionnaire

He analysis of the data produced for the content expert test gets a percentage of $81.6 \%$, design experts get a percentage of $80 \%$, media experts get a $95 \%$ percentage result so that the module is well qualified from the overall expert test

Key words : Instruksional, teaching module, Storyboard

\section{PENDAHULUAN}

Pendidikan memiliki peran yang sangat penting dalam kemajuan suatu bangsa dan negara. Berbagai usaha telah dilakukan pemerintah untuk mencapai tujuan pendidikan salah satunya adalah dengan meningkatkan mutu pendidikan. Menurut Kristianto dalam [3] peningkatan mutu pendidikan tidak cukup dengan pembaharuan kurikulum, penyediaan buku-buku dan 


\section{ISSN 2252-9063 \\ Kumpulan Artikel Mahasiswa Pendidikan Teknik Informatika}

(KARMAPATI)

Volume 8, Nomor 2, 2019

perbaikan sarana belajar lainnya, tetapi juga perlu disertai peningkatan penggunaan media pembelajaran yang tepat baik elektronik maupun non elektronik.

Seorang guru harus memiliki pegangan bahan ajar dan media bantu, media bantu dapat berupa modul, buku teks, video, media berbasis komputer, internet dan lainlain. Menurut Arsyad dalam [2] media pembelajaran dapat memperjelas penyajian pesan dan informasi sehingga dapat memperlancar dan meningkatkan proses dan hasil belajar. SMK (Sekolah Menengah Kejuruan) merupakan salah satu lembaga pendidikan yang memiliki tanggung jawab untuk menciptakan sumberdaya manusia (SDM) yang memiliki keahlian, kemampuan dan keterampilan sehingga lulusanya dapat mengembangakan kinerja saat berada di dunia kerja.

Salah satunya adalah SMK TI Bali Global Singaraja. SMK TI Bali Global Singaraja ini bergerak pada bidang teknologi yang mana pada tahun ini SMK TI Bali Global Singaraja menerapkan kurikulum terbaru yaitu kurikulum 2013. Kurikulum 2013 digagas untuk mencetak generasi yang siap dalam menghadapi masa depan dan untuk mendorong peserta didik atau siswa mampu lebih baik dalam melakukan observasi, bertanya, bernalar, dan mengkomunikasikan (mempresentasikan) apa yang mereka proleh atau mereka ketahui setelah meneriman materi pembelajaran, sehingga diharapkan siswa memiliki kompetensi sikap, keterampilan dan pengetahuan jauh lebih baik, kreatif, inovatif dan lebih produktif dengan menggunakan pendekatan scientific.

SMK TI Bali Global Singaraja memiliki 4 pilihan Kompetensi Keahlian atau Jurusan yaitu; Multimedia, Teknik Komputer \& Jaringan (TKJ), Akutansi berbasis Komputer, dan yang terakhir Rekayasa Perangkat Lunak (RPL). Jurusan Multimedia memiliki beberapa mata pelajaran wajib yang harus dijalankan oleh siswa, salah satu mata pelajarannya yaitu Storyboard. Menurut Luther, Storyboard merupakan deskripsi dari setiap scene yang secara jelas menggambarkan obyek multimedia serta perilakunya. Storyboard merupakan area berisi dari sebuah gambar sketsa yang digunakan sebagai alat perencanaan untuk menunjukkan secara visual bagaimana aksi dari sebuah cerita. Tujuan utama Storyboard adalah untuk menjelaskan tentang alur narasi dari sebuah cerita. Storyboard juga berperan dalam pewaktuan pada sebuah sequence, sudut pandang kamera, perpindahan dan kesinambungan anatara elemen dalam satu frame.

Bahan ajar untuk mata pelajaran Storyboard sulit didapatkan di sekolah ini dan buku atau bahan ajar yang membahas materi tersebut belum memadai. Setiap proses pembelajaran yang sudah dilakukan, guru mengajar belum menggunakan panduan yang sistematis. Hal ini mengakibatkan materi yang diberikan pada mata pelajaran ini tidak sepenuhnya lengkap disampaikan. Tidak adanya bahan ajar atau modul yang di berikan mengakibatkan proses belajar mengajar terhabat dikarenakan siswa kurang memahami materi yang di berikan.

Dikarenakan kurikulum 2013 menuntut peserta didik agar lebih kreatif dan inovatif dengan menggunakan pendekatan scientific, maka model pembelajaran yang sesuai dengan mata pelajaran dan kurikulum saat ini adalah Project Based Learning (pembelajaran berbasis project). Model pembelajaran berbasis proyek (project based learning) adalah suatu model pembelajaran yang menyangkut pemusatan pertanyaan dan masalah yang bermakna, pemecahan masalah, pengambilan keputusan, proses pencarian berbagai sumber, pemberian kesempatan kepada anggota untuk bekerja secara kolaborasi, dan menutup dengan presentasi produk nyata [4]. Dalam pembelajaran berbasis proyek, siswa dituntut untuk merumuskan tujuan pembelajaran sendiri secara khusus. Proyek apa yang ingin dibuat harus didasarkan pada minat dan ke tnampuan siswa baik secara pribadi maupun kelompok. Siswa juga dituntut untuk mengatur sendiri kegiatan belajarnya dengan membagi beban kerja di antara mereka dan mengintegrasikan tugas-tugas yang berbeda yang dikembangkan oleh masing-masing siswa.

Berdasarkan latar belakang dan identifikasi permasalahan yang diuraikan di atas maka pada kesempatan ini peneliti akan melaksanakan penelitian dengan topik "Pengembangan Modul Ajar Storyboard Berbasis Project Based Learning Untuk Siswa Kelas XI Multimedia di SMK TI Bali Global Singaraja”.

\section{KAJIAN TEORI}

\section{Teori Belajar \\ a. Teori Belajar Kognitivisme}

Dasar pemikiran teori belajar kognitivisme adalah rasional. Teori ini memiliki asumsi filosofis, yaitu the way in which we learn [5]. Pengetahuan seseorang diperoleh berdasarkan pemikiran. Inilah yang disebut dengan filosofi Rasionalism. Menurut teori ini, peserta didik belajar disebabkan oleh kemampuan peserta didik dalam menafsirkan peristiwa yang terjadi di dalam lingkungan. Teori ini menjelaskan bagaimana belajar terjadi dan menjelaskan secara alami kegiatan mental internal dalam diri peserta didik. Oleh karena itu, teori kognitivisme lebih mementingkan proses belajar daripada hasil belajar itu sendiri. Menurut teori ini bahwa belajar melibatkan proses berpikir yang kompleks. Prinsip dasar yang mendasari teori belajar kognitif adalah teori psikologi.

\section{b. Teori Belajar Behavioristik}




\section{ISSN 2252-9063 \\ Kumpulan Artikel Mahasiswa Pendidikan Teknik Informatika}

(KARMAPATI)

Volume 8, Nomor 2, 2019

Teori belajar behavioristik adalah sebuah teori yang dicetuskan oleh Gage dan Berliner tentang perubahan tingkah laku sebagai hasil dari pengalaman. Teori ini lalu berkembang menjadi aliran psikologi belajar yang berpengaruh terhadap arah pengembangan teori dan praktek pendidikan dan pembelajaran yang dikenal sebagai aliran behavioristik. Aliran ini menekankan pada terbentuknya perilaku yang tampak sebagai hasil belajar. Teori behavioristik dengan model hubungan stimulusresponnya, mendudukkan orang yang belajar sebagai individu yang pasif. Respons atau perilaku tertentu menggunakan metode pelatihan atau pembiasaan semata. Munculnya perilaku akan semakin kuat bila diberikan penguatan dan akan menghilang bila dikenai hukuman.

\section{c. Teori Belajar Konstruktivisme}

Belajar menurut pandangan konstruktivisme lebih diarahkan pada terbentuknya makna pada diri pemelajar atas apa yang dipelajarinya berdasarkan pengetahuan dan pemahaman mereka sebelumnya. Dalam proses ini lebih ditekankan pada terbentuknya hubungan-hubungan makna antara pengetahuan yang telah ada dan pengetahuan baru dengan fasilitasi kreativitas guru selaku mediator pembelajaran. Dengan demikian, dilihat dari dimensi pembelajaran, model konstruktivisme memandang belajar itu sebagai sebuah proses modifikasi ide dan pengetahuan yang telah dimiliki oleh siswa menuju terbentuknya pengetahuan baru. Dalam proses ini siswa secara aktif terlibat dalam upaya penemuan makna dari apa yang dipelajarinya, sehingga secara langsung berdampak pada tumbuh dan berkembangnya keterampilan berpikir mereka selama pembelajaran berlangsung. Di samping itu, aplikasi model konstruktivis memungkinkan siswa untuk menguasai materi pelajaran secara lebih komprehensif dan bermakna, mengingat mereka terlibat secara aktif selama berlangsungnya pembelajaran.

\section{d. Koneksionisme}

Koneksionisme merupakan teori yang paling awal dari rumpun Berhaviorisme. Teori belajar koneksionisme dikembangkan oleh Edward L. Thorndike (1874-1949). Pendidikan yang dilakukan Thorndike adalah menghadapkan subjek pada situasi yang mengandung problem. Model eksperimen yang ditempuhnya sangat sederhana, yaitu dengan menggunakan kucing sebagai objek penelitiannya. Kucing dalam keadaan lapar dimasukkan ke dalam kandang yang dibuat sedemikian rupa, dengan model pintu yang dihubungkan dengan tali.media dan metode pembelajaran yang dapat menggambarkan materi yang kompleks.

\section{Teknik Pembuatan Storyboard}

Storyboard merupakan gambar sketsa yang dibuat pada panel-panel yang berentuk segi empat, yang disusun berurutan dan saling berkelanjutan membentuk sebuah alur cerita sesuai naskah [1]. Storyboard dapat dibuat dengan 2 cara, yaitu :

a. Penggambaran cerita dalam bentuk strip (potonganpotongan gambar) sesuai perkiraan tampilan yang diharapkan di layar (seperti komik), disertai penjelasan lengkap mengenai cerita.

b. Membuat Storyboard dengan simbol, (ditujukan bagi yang tidak bisa menggambar).

Jadi bentuk Storyboard bisa dibuat dengan simbolsimbol yang bisa dimengerti oleh orang lain. Contoh: penggambaran manusia dibuat dengan bentuk garis dan kepala bulat, atau bentuk simbol bahwa gambar dimaksud adalah manusia. Storyboard model ini harus diberi penjelasan maksud simbol tersebut.

\section{Model Pengembangan Instruksional}

Secara umum MPI menurut Suparman dalam [6] terdiri dari tiga tahap yaitu tahap mengidentifikasi, tahap mengembangkan, dan tahap mengevaluasi dan merevisi.

\section{a. Mengidentifikasi kebutuhan instruksional}

Mengidentifikasi kebutuhan instruksional adalah suatu proses untuk: a) menentukan kesenjangan penampilan siswa yang disebabkan kekurangan kesempatan mendapatkan pendidikan dan pelatihan pada masa lalu; b) mengidentifikasi bentuk kegiatan instruksional yang paling tepat; c) menentukan populasi sasaran yang dapat mengikuti kegiatan instrusional tersebut.

b. Melakukan analisis instruksional

Analisis instruksional adalah proses menjabarkan kompetensi umum menjadi subkomptensi, kompetensi dasar, atau kompetensi khusus yang tersusun secara logis dan sistematik. Kegiatan tersebut dimaksudkan untuk mengidentifikasi daftar subkompetensi dan menyusun hubungan antara sub kompetensi yang satu dan subkompetensi yang lain menuju kompetensi umum.

c. Mengidentifikas Perilaku Dan Karakteristik Siswa

Langkah selanjutnya mengidentifikasi karakteristik siswa yang berhubungan dengan keperluan pengembangan instruksional. Informasi yang dikumpulkan terbatas kepada karakteristik siswa yang ada manfaatnya dalam proses pengembangan instruksional. Misalnya minat siswa, kemampuan siswa dalam membaca bahasa asing, atau informasi lain yang berhubungan dengan pengembangan instruksional. 


\section{d. Menulis Tujuan Instruksional Khusus}

Tujuan instructional umum (TIU) atau tujuan instruktional akhir. TIK dirumuskan dalam bentuk kata kerja yang dapat dilihat oleh mata (observable). TIK merupakan satu-satunya dasar untuk menyusun kisi-kisi tes, karena itu TIK harus mengandung unsur-unsur yang dapat memberikan petunjuk kepada penyusun tes agar dapat mengembangkan tes yang benar-benar dapat mengukur perilaku yang terdapat di dalamnya.

e. Menulis Tes Acuan Patokan

Unsur-unsur dalam TIK dikenal dengan ABCD yang berasal dari kata sebagai berikut: $\mathrm{A}=$ Audience, $\mathrm{B}=$ Behavior, $\mathrm{C}=$ Condition, dan $\mathrm{D}=$ Degree. Audience adalah siswa yang akan belajar, behavior adalah perilaku spesifik yang akan dimunculkan oleh siswa setelah selesai proses belajarnya dalam pelajaran tersebut, condition adalah kondisi atau batasan yang dikenakan kepada siswa atau alat yang digunakan siswa pada saat di tes (bukan pada saat belajar), dan degree adalah tingkat keberhasilah siswa dalam mencapai perilaku tersebut.

\section{f. Menyusun strategi instruksional}

Alat penilaian hasil belajar yang mengacu kepada tujuan instruksiaonal disebut alat penilaian acuan patokan. Selanjutnya, hasil belajar setiap peserta didik dibandingkan dengan tingkat pencapaiaan kompetensi dalam tujuan instruksional tersebut. Tes acuan patokan dimaksudkan untuk mengukur tingkat penguasaan setiap siswa terhadap perilaku yang tercantum dalam TIK. Adapun langkahlangkah dalam menyusun tes acuan patokan adalah sebagai berikut: a) menentukan tujuan tes; b) membuat table spesifikasi untuk setiap tes yaitu daftar perilaku, bobot perilaku, persentase jenis tes, dan jumlah butir tes; c) menulis butir tes; d) merakit tes; e) menulis petunjuk; f) menulis kunci jawaban; g) mengujicobakan tes; h) menganalisis hasil ujicoba; i) merevisi tes.

g. Mengembangkan bahan instruksional

Dalam strategi instruksional terkadung empat pengertian sebagai berikut: a) urutan kegiatan instruksional, yaitu terdiri atas komponen pendahuluan, penyajian, dan penutup; b) garis besar isi, yaitu menunjukkan judul isi pembelajaran yang konsisten dengan urutan tujuan instruksional yang mengacu pada peta konsep; c) metode instruksional, yaitu cara guru mengorganisasikan materi pelajaran dan siswa agar terjadi proses belajar secara efektif dan efisien; d) media dan alat instruksional, yaitu peralatan dan bahan instruksional yang digunakan guru dan siswa dalam kegiatan instruksional; dan d) waktu yang digunakan dalam menyelesaikan setiap langkah dalam kegiatan instruksional.

h. Mendesain Dan Melaksanakan Evaluasi Formatif Yang Termasuk Di Dalamnya Kegiatan Merevisi

Bentuk kegiantan instruksional ada tiga macam sehingga melahirkan tiga bentuk bahan instruksional. 1) pengembangan bahan instruksional mandiri, yaitu bahan belajar mandiri dikembangakan bila dalam pelaksanaan kegiatan instruksional peserta didik belajar secara mandiri, tanpa tergantung kehadiran pengajar; 2) pengembangan bahan instruksional kompilasi, yaitu untuk mengembangkan bahan kompilasi pendesain instruksional memilih dan mengumpulkan berbagai bahan instruksional yang kebetulan tersedia di lapangan sepanjang itu relevan dengan strategi instruksional yang telah dimilikinya; dan 3) pengembangan bahan instruksional kombinasi, yaitu dikembangkan berdasarkan keputusan awal tentang daftar program studi, matakuliah, kurikulum diklat atau mata pelajaran yang akan digunakan sebagai bahan pembelajaran mandidri dan tatap muka. Evaluasi formatif sebagai proses mnyediakan dan menggunakan informasi untuk dijadikan dasar pengambilan keputusan dalam rangka meningkatkan kualitas produk atau program instruksional. Tahapan evaluasi formatif adalah sebagai berikut: a) review oleh ahli bidang studi di luar tim pengembangan instruksional; b) evaluasi satu-satu (one-to-one evaluation); c) evaluasi kelompok kecil; dan d) ujicoba lapangan.

\section{Modul Ajar}

Modul pembelajaran merupakan satuan program belajar mengajar yang terkecil, yang dipelajari oleh siswa sendiri secara perseorangan atau diajarkan oleh siswa kepada dirinya sendiri (self-instructional) [10]. Vembriarto dalam [9], menyatakan bahwa suatu modul pembelajaran adalah suatu paket pengajaran yang memuat satu unit konsep dari pada bahan pelajaran. Pengajaran modul merupakan usaha penyelanggaraan pengajaran individual yang memungkinkan siswa menguasai satu unit bahan pelajaran sebelum dia beralih kepada unit berikutnya. beberapa pengertian modul di atas maka dapat disimpulkan bahwa modul pembelajaran adalah salah satu bentuk bahan ajar yang dikemas secara sistematis dan menarik sehingga mudah untuk dipelajari secara mandiri.

\section{a. Kelebihan dan Kelemmahan Modul}

Tjipto dalam [8], mengungkapkan beberapa keuntungan yang diperoleh jika belajar menggunakan modul, antara lain : 
1) Motivasi siswa dipertinggi karena setiap kali siswa mengerjakan tugas pelajaran dibatasi dengan jelas dan yang sesuai dengan kemampuannya.

2) Sesudah pelajaran selesai guru dan siswa mengetahui benar siswa yang berhasil dengan baik dan mana yang kurang berhasil.

3) Siswa mencapai hasil yang sesuai dengan kemampuannya.

4) Beban belajar terbagi lebih merata sepanjang semester.

5) Pendidikan lebih berdaya guna.

Menurut Suparman dalam [6], menyatakan bahwa bentuk kegiatan belajar mandiri ini mempunyai kekurangan-kekurangan sebagai berikut :

1) Biaya pengembangan bahan tinggi dan waktu yang dibutuhkan lama.

2) Menentukan disiplin belajar yang tinggi yang mungkin kurang dimiliki oleh siswa pada umumnya dan siswa yang belum matang pada khususnya.

3) Membutuhkan ketekunan yang lebih tinggi dari fasilitator untuk terus menerus mamantau proses belajar siswa, memberi motivasi dan konsultasi secara individu setiap waktu siswa membutuhkan.

\section{b. Karakteristik Modul}

1) Self Instruction (instruksi Mandiri)

Merupakan karakteristik penting dalam modul, dengan karakter tersebut memungkinkan seseorang belajar secara mandiri dan tidak tergantung pada pihak lain.

2) Self Contained

Modul dikatakan self contained bila selmuh materi pembelajaran yang dibutuhkan termuat dalam modul tersebut. Tujuan dari konsep ini adalah memberikan kesempatan belajar peserta didik mempelajari materi pembelajaran secara tuntas, karena materi belajar dikemas ke dalam satu kesatuan yang utuh.

3) Berdiri Sendiri (Stand alone)

Stand alone atau berdiri sendiri merupakan karakteristik modul yang tidak tergantung pada bahan ajar atau media lain. Dengan menggunakan modul, peserta didik tidak perlu bahan ajar yang lain untuk mempelajari dan mengerjakan tugas pada modul tersebut.

4) Adaptif

Modul hendaknya memiliki daya adaptasi yang tinggi terhadap perkembangan ilmu dan teknologi. Dikatakan adaptif jika modul tersebut dapat menyesuaikan perkembangan ilmu pengetahuan dan teknologi, serta fleksibel digunakan di berbagai perangkat keras (hardware).

5) Bersahabat/Akrab (User Friendly)

Modul hendaknya juga memenuhi kaidah user friendly atau bersahabat/akrab dengan pemakainya. Setiap instruksi dan paparan informasi yang tampil bersifat membantu dan bersahabat dengan pemakainya, termasuk kemudahan pemakai dalam merespon dan mengakses sesuai dengan keinginan. Penggunaan bahasa yang sederhana, mudah dimengerti, serta menggunakan istilah yang umum digunakan, merupakan salah satu bentuk user friendly.

6) Desain

Langkah awal yang perlu dilakukan dalam pengembangan suatu modul adalah menetapkan desain atau rancangannya. Kedudukan desain dalam pengembangan modul adalah sebagai salah satu dari komponen prinsip pengembangan yang mendasari dan memberi arah teknik dan tahapan penyusunan modul.

\section{Project Based Learning}

Model pembelajaran berbasis proyek adalah suatu model pembelajaran yang menyangkut pemusatan pertanyaan dan masalah yang bermakna, pemecahan masalah, pengambilan keputusan, proses pencarian berbagai sumber, pemberian kesempatan kepada anggota untuk bekerja secara kolaborasi, dan menutup dengan presentasi produk nyata [7].

Karakteristik pembelajaran berbasis proyek meliputi aspek isi, kegiatan, kondisi, dan hasil. Dalam pembelajaran berbasis proyek, aspek isi pembelajaran memiliki karakteristik: (1) masalah disajikan dalam bentuk keutuhan yang kompleks; (2) siswa menemukan hubungan antar ide secara interdisipliner; (3) siswa berjuang mengatasi ambiguitas; dan (4) menjawab pertanyaan yang nyata dan menarik perhatian siswa. Aspek kegiatan memiliki karakteristik: (1) siswa melakukan investigasi selama periode tertentu; (2) siswa dihadapkan pada suatu kesulitan, pencarian sumber dan pemecahan masalah, (3) siswa membuat hubungan antar ide dan memperoleh keterampilan baru; (4) siswa menggunakan perlengkapan alat sesungguhnya, dan (5) siswa menerima feedback tentang gagasannya dari orang lain.

Menurut Moursund yang di kutip oleh Wena keuntungan project based learning adalah :

1. Meningkatkan motivasi,

2. Meningkatkan kemampuan memecahkan masalah;

3. Meningkatkan kemampuan studi pustaka;

4. Meningkatkan kolaborasi; 


\section{ISSN 2252-9063 \\ Kumpulan Artikel Mahasiswa Pendidikan Teknik Informatika}

(KARMAPATI)

Volume 8, Nomor 2, 2019

5. Meningkatkan keterampilan manajemen sumber daya.

Kelemahan atau kekurangan model project based learning menurut (Kementrian Pendidikan dan Kebudayaan, 2013) diantaranya yaitu:

a. Memerlukan banyak waktu untuk menyelesaikan masalah.

b. Membutuhkan biaya yang cukup banyak.

c. Banyak instruktur yang merasa nyaman dengan kelas tradisioal, dimana instruktur memegang peran utama di kelas.

d. Banyak peralatan yang harus disediakan.

e. Peserta didik yang memiliki kelemahan dalam percobaan dan pegumpulan informasi akan mengalami kesulitan.

f. Ada kemungkinan peserta didik yang kurang aktif dalam kerja kelompok.

g. Susahnya mengendalikan situasi di kelas karena bekerja kelompok.

Menurut Thomas [7], project based learning memiliki beberapa prinsip dalam penerapannya. Prinsipprinsip tersebut adalah : 1 . Pertanyaan penuntun 2 . Investigasi konstruktif 3. Otonomi 4.Realistis

Mengacu kepada prinsip-prinsip tersebut diatas, maka pembelajaran dengan menerapkan project based learning akan sangat bermanfaat bagi pengembangan didri dan masa depan siswa. Siswa yang terbiasa belajar dengan pekerjaan proyek akan menjadi pribadi yang ulet, kritis, mandiri dan produktif.

Tahap pembelajaran parktik kejuruan berbasis proyek dibagi menjadi tiga tahap, yaitu tahap perencanaan, tahap pelaksanaan dan tahap evaluasi. Tahap perencanaan pembelajaran proyek meliputi kegiatan merumuskan tujuan proyek; menganalisis karakteristik siswa; merumuskan strategi pemebelajaran; membuat jobsheet; merencanakan kebutuhan sumber belajar yang diperlukan; menjelaskan tugas proyek; mengelompokkan siswa sesuai dengan tugas dan mengerjakan proyek. Tahap evaluasi dilakukan utuk mengetahui ketercapaian tujuan pembelajaran oles siswa. Hasil evaluasi menjadi bahan masukan bagi siswa dan bagi guru untuk merencanakan pembelajaran sebelumnya.

\section{METODE PENELITIAN}

\section{Jenis Penelitian}

Penelitian ini merupakan jenis Penelitian Pengembangan atau dalam bahasa Inggrisnya Research and Development ( $\mathrm{R} \& \mathrm{D})$ yakni metode penelitian yang digunakan untuk menghasilkan produk tertentu, dan menguji kefektifan produk tersebut model pengembangan Instruksional. Adapun tahapan pada model pengembangan Instruksional diantaranya : tahap mengidentifikasi (Mengidentifikasi kebutuhan instruksional dan menulis tujuan instruksional umum, Melakukan analisis instruksional, Mengidentifikas perilaku dan karakteristik siswa), tahap mengembangkan(Menulis tujuan instruksional khusus, Menulis tes acuan patokan, Menyusun strategi instruksional, Mengembangkan bahan instruksional), dan tahap mengevaluasi dan merevisi (Mendesain dan melaksanakan evaluasi formatif yang termasuk di dalamnya kegiatan merevisi)

\section{Teknik Pengumpulan Data}

Data yang dikumpulkan untuk dianalisis dalam penelitian ini meliputi informasi tentang sumber belajar. Sumber belajar dikumpulkan dengan menggunakan metode wawancara. Metode wawancara digunakan untuk mengetahui secara langsung kurikulum yang berlaku di sekolah serta ketersediaan sumber belajar mata pelajaran Storyboard untuk multimedia yang tertuang dalam bentuk silabus. Adapun sumber data pada saat wawancara tersebut adalah guru yang pernah mengajar mata pelajaran Storyboard untuk multimedia.

\section{Validasi Modul}

Validasi modul di uji oleh ahli isi, ahli desain, ahli media, evaluasi satu-satu dan evaluasi kelompok kecil, menganalisis respon siswa terhadap pengembangan modul. Untuk hasil penilaian semua validasi di atas dihitung dengan Persamaan [1]:

$$
\text { Persentase }=\frac{\text { Skor Perolehan }}{\text { Skor Maksimal }}
$$

Kemudian untuk melihat tingkat pencapaian pengembangan modul berdasarkan perhitungan persentase maka ditetapkan kriteria sesuai tabel tingkat pencapaian seperti terlihat pada Tabel 1.

Tabel 1 Konversi Tingkat Pencapaian
\begin{tabular}{|l|l|l|}
\hline $\begin{array}{c}\text { Tingkat } \\
\text { Pencapaian }\end{array}$ & Kualifikasi & Keterangan \\
\hline $90 \%-100 \%$ & Sangat Baik & Tidak perlu direvisi \\
\hline $75 \%-89 \%$ & Baik & Tidak perlu direvisi \\
\hline $65 \%-74 \%$ & Cukup & Direvisi \\
\hline $55 \%-64 \%$ & Kurang & Direvisi \\
\hline $0-54$ & Sangat Kurang & Direvisi \\
\hline
\end{tabular}

\section{HASIL DAN PEMBAHASAN}




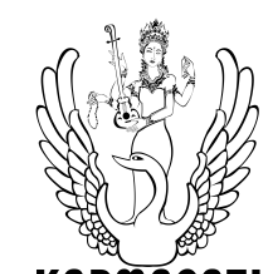

ISSN 2252-9063

Kumpulan Artikel Mahasiswa Pendidikan Teknik Informatika

(KARMAPATI)

KARMAPATI

Volume 8, Nomor 2, 2019

Berdasarkan pengolahan data yang dilakukan maka dapat diuraikan hasil dan pembahasan penelitian sebagai berikut.

\section{Hasil}

Hasil penelitian yang telah dihasilkan adalah sebuah modul ajar yang valid pada Mata Pelajaran Storyboard Untuk Multimedia untuk kelas XI di SMK TI Bali Global Singaraja seperti pada Gambar 1.

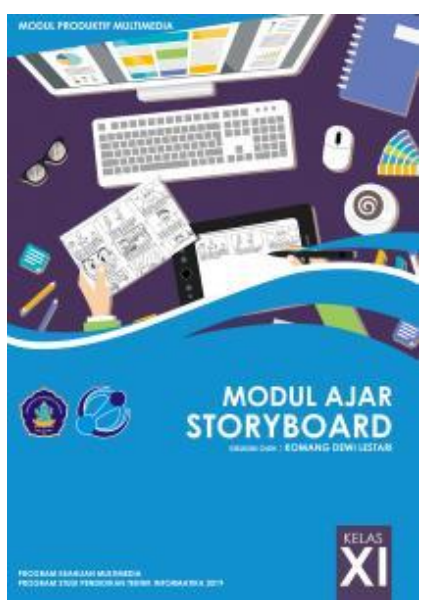

Gambar 1. Modul Ajar

Adapun hasil penilaian berdasarkan angket yang diberikan untuk uji ahli isi dapat dihitung persentase tingkat pencapaian modul ajar Storyboard untuk multimedia dengan Persamaan [1]. Maka persentase hasil penilaian dari ahli isi dapat dihitung.

$$
\begin{aligned}
& \text { Persentase }=\text { - } \begin{array}{c}
\text { Skor Perolehan } \\
\text { Skor Maksimal }
\end{array} \quad \text { X 100\% } \\
& 98 \\
& \text { Persentase }=-\frac{9}{120} \text { X } 100 \%=81,6 \%(\text { Uji Ahli Isi 1) } \\
& \text { Persentase }=\frac{98}{120} \text { X } 100 \%=81,6 \%(\text { Uji Ahli Isi 2) }
\end{aligned}
$$

Kemudian untuk ahli desain peneliti memberikan modul ajar sekaligus angket penilaian. Adapun hasil presentase ahli desain dapat dihitung.

$$
\begin{aligned}
\text { Persentase }= & \stackrel{96}{120} \text { X 100\% }=80 \% \quad(\text { Uji Ahli Desain } 1) \\
& 99 \\
\text { Persentase }= & ---- \text { X 100\% }=82,5 \%(\text { Uji Ahli Desain } 2)
\end{aligned}
$$

120

Untuk ahli media, peniliti juga memberikan modul ajar dan angket penilaian. Adapun hasil presentase ahli desain dapat dihitung

$$
\begin{aligned}
\text { Persentase }= & \begin{array}{l}
114 \\
120
\end{array} \\
& 120 \\
\text { Persentase }= & -\begin{array}{l}
120 \\
120
\end{array}
\end{aligned}
$$

Setelah melakukan uji ahli peneliti melakukan evaluasi satu-satu yang dilakukan terhadap 3 (tiga) orang siswa.Setiap siswa yang dijadikan responden diberikan 1 (satu) modul ajar Storyboard untuk multimedia dan instrumen penilaian (draft wawancara).Maka dapat dianalisis pada penempatan pertanyaan yang kurang tepat. Kemudian penempatan materi dan soal kurang tepat. Kemudian berdasarkan evaluasi satu-satu, peneliti melakukan evaluasi kelompok kecil dilakukan terhadap 9 (sembilan) orang siswa. Setiap siswa yang dijadikan responden diberikan 1 (satu) modul ajar menerapkan prinsip-prinsip seni grafis dalam desain komunikasi visual untuk multimedia dan instrumen penilaian (angket). Berdasarkan evaluasi kelompok kecil hasil rekaptulasi tingkat pencapaian pada evaluasi evaaluasi kelompok kecil disajikan pada Tabel 2

Tabel 2 Rekaptulasi Penilaian pada Evaluasi Kelompok Kecil

\begin{tabular}{|c|c|c|}
\hline $\begin{array}{c}\text { Konversi tingkat } \\
\text { pencapaian }\end{array}$ & $\begin{array}{c}\text { Persentase } \\
(\%)\end{array}$ & $\begin{array}{c}\text { Jumlah } \\
\text { Responden } \\
\text { (orang) }\end{array}$ \\
\hline Sangat Baik & $37,3 \%$ & 3 \\
\hline Baik & $62,6 \%$ & 6 \\
\hline Cukup & $0 \%$ & 0 \\
\hline Kurang & $0 \%$ & 0 \\
\hline Sangat Kurang & $0 \%$ & 0 \\
\hline
\end{tabular}

Setelah melakukan evaluasi kelompok kecil modul direvisi sehingga modul sudah siap diuji cobakan ke siswa dengan menerapkan modul terebut dalam pembelajaran. Peneliti melibatkan 15 (lima belas) orang siswa untuk menerapkan modul ajar menerapkan prinsip-prinsip seni grafis dalam desain komunikasi visual untuk multimedia. Hasil penilaian presentase uji 
lapangan dengan menggunakan persamaan [1] sebagai berikut.

Tabel 3. Rekapitulasi Penilaian Siswa dalam Uji Lapangan

\begin{tabular}{|c|c|c|}
\hline $\begin{array}{c}\text { Konversi tingkat } \\
\text { pencapaian }\end{array}$ & $\begin{array}{c}\text { Persentase } \\
(\%)\end{array}$ & $\begin{array}{c}\text { Jumlah } \\
\text { Responden } \\
\text { (orang) }\end{array}$ \\
\hline Sangat Baik & $53 \%$ & 8 \\
\hline Baik & $47 \%$ & 7 \\
\hline Cukup & $0 \%$ & 0 \\
\hline Kurang & $0 \%$ & 0 \\
\hline Sangat Kurang & $0 \%$ & 0 \\
\hline
\end{tabular}

\section{Pembahasan}

Hasil perhitungan persentase untuk ahli isi adalah 81,6 \% hasil tersebut dikonversikan ke dalam tabel konversi yang terdapat pada Tabel 1, sehingga dari presentase tingkat pencapaian modul ajar storyboard untuk multimedia berada dalam kualifikasi baik, sehingga tidak perlu direvisi. Hal ini mengidentifikasi bahwa modul storyboard untuk multimedia sudah valid dari segi isi atau materi. Kemudian hasil perhitungan persentase untuk ahli desain adalah $83 \%$, hasil tersebut dikonversikan, sehingga dari presentase tingkat pencapaian modul ajar storyboard untuk multimedia berada dalam kualifikasi baik, sehingga tidak perlu direvisi. Hal ini mengidentifikasi bahwa modul ajar menerapkan storyboard untuk multimedia sudah valid dari segi desain yang digunakan. Hasil perhitungan persentase untuk ahli media adalah $95 \%$ kemudian hasil tersebut dikonversikan ke dalam tabel, sehingga dari prsentase tingkat pencapaian modul ajar storyboard untuk multimedia berada dalam kualifikasi sangat baik, sehingga tidak perlu direvisi. Hal ini mengidentifikasi bahwa modul ajar storyboard untuk multimedia sudah valid dari segi media yang ditampilkan.

Berdasarkan hasil penilaian pada Tabel 2, adapun pemaparan beberapa masukan yang telah dirangkum oleh peneliti sebagai dasar untuk melakukan revisi pada modul ajar yaitu : Tes sudah baik namun kurang banyak. Menanggapi adanya masukan tersebut peneliti telah melakukan revisi dengan menambah soal evaluasi pada modul.

Berdasarkan rekapitulasi penilaian dari masingmasing responden penilaian yang diberikan oleh siswa adalah sangat baik $37,3 \%$, baik $62,6 \%$, cukup $0 \%$, kurang $0 \%$ dan sangat kurang $0 \%$. Penilaian ini sejalan dengan rerata skor seluruh responden yang diperoleh pada analisis yang tertera pada Tabel 2.
Selanjutnya rerata persentase uji lapangan yaitu $88 \%$, bila dikonversikan ke dalam tabel konversi berada dalam kualifikasi baik.

Berdasarkan rekapitulasi penilaian dari masingmasing responden yang terlihat pada Tabel 3 memperlihatkan penilaian yang diberikan oleh siswa adalah sangat baik $53 \%$, baik 47\%, cukup 0\%, kurang $0 \%$ dan sangat kurang $0 \%$.

\section{SIMPULAN}

Berdasarkan hasil penelitian dan pembahasan pada penelitian pengembangan modul ajar storyboard berbasis project based learning untuk multimedia dapat disimpulkan beberapa hal sebagai berikut:

1. Pengembangan modul ajar storyboard berbasis project based learning untuk multimedia di SMK TI Bali Global menggunakan model pengembangan instruksional. Adapun tahapan yang dilakukan dalam pengembangan ini diantaranya: tahap mengidentifikasi (Mengidentifikasi kebutuhan instruksional dan menulis tujuan instruksional umum, Melakukan analisis instruksional, Mengidentifikas perilaku dan karakteristik siswa), tahap mengembangkan (Menulis tujuan instruksional khusus, Menulis tes acuan patokan, Menyusun strategi instruksional, Mengembangkan bahan instruksional), dan tahap mengevaluasi dan merevisi (Mendesain dan melaksanakan evaluasi formatif yang termasuk di dalamnya kegiatan merevisi).

2. Adapun analisis data yang dihasilkan untuk uji ahli isi mendapatkan hasil presentase $81,6 \%$, ahli desain mendapatkan hasil presentase $80 \%$, ahli media mendapatkan hasil presentase $95 \%$ sehingga modul berada pada kualifikasi baik dari keseluruhan uji ahli.

3. Adapun hasil respon siswa terhadap modul ajar storyboard untuk multimedia di SMK TI Bali Global Singaraja, melalui uji lapangan siswa memberikan penilaian dengan rata-rata persentase $88 \%$ sehingga jika dikonversikan persentase tersebut dalam kualifikasi baik.

Berdasarkan pengamatan penulis, terdapat beberapa hal yang dapat dijadikan bahan pertimbangan untuk ditindak lanjuti.

1. Melakukan evaluasi sumatif untuk mengetahui efektifitas penggunaan modul ajar storyboard untuk multimedia. 
ISSN 2252-9063

Kumpulan Artikel Mahasiswa Pendidikan Teknik Informatika

(KARMAPATI)

Volume 8, Nomor 2, 2019

\section{KARMAPATI}

2. Mengembangkan modul dalam versi e-learning. 
ISSN 2252-9063

Kumpulan Artikel Mahasiswa Pendidikan Teknik Informatika

(KARMAPATI)

Volume 8, Nomor 2, 2019

\section{REFRENSI}

[1] Andreas, D. (2013). Cara Mudah Merancang Storyboard unruk Animasi Keren. Yogyakarta: TAKA Publisher.

[2] Arsyad, A. (2006). Media pembelajaran. Jakarta: Raja Grafindo Persada

[3] Kristianto, A. (2011). Pengembangan Model Media Video Pembelajaran Mata Kuliah Pengembangan Media Video/TV Program Studi Teknologi Pendidikan Fakultas Ilmu Pendidikan Universitas Negeri Surabaya. Retrieved April 25, 2018, from http://jurnalteknologi-pendidikan.tp.ac.id

[4] Rath, F. K. (2007). M Project Based Learning and Learning Environments. Journal In Informing Science and Information Technology, 107.

[5] Sudrajat, A. (2008). Pengertian Pendekatan, Strategi, Metode, Teknik dan Model Pembelajaran. Bandung: Sinar Baru Algensindo.

[6] Suparman, M. A. (2012). Panduan Para Pengajar \& Inovator Desain Instruksional Modern. Jakarta: Erlangga.

[7] Thomas, W. J. (2000). 'a review of research on project-based learning'. Retrieved from California the autodesk foundation: http:www.autodesk.com (diakses pada tanggal 21 Oktober 2016).

[8] Tjipto, U. (1991). Peningkatan dan Pengembangan Pendidikan. Jakarta: Gramedia Pustaka Utama.

[9] Vembriarto, S. (1987). Pengantar Pengajaran Modul. Yogyakarta

[10]Winkel. (2009). Modul Ajar Pengembangan dan Evaluasi. Jakarta: Pusat Penerbitan UT. 